\title{
Analytical description of the specific electric conductivity of halogenides KHal melts and its calculation for the KAt melt
}

\author{
(C) Ivan K. Garkushin, ${ }^{*}$ Olga V. Lavrenteva, Yana A. Andreeva, and Karina R. Gilmanova \\ Department of General and Inorganic Chemistry. Samara State Technical University. \\ Molodogvardeyskaya St., 244. Samara, 443100. Samara Region. Russia. \\ Phone:+7 (846) 278-44-77.E-mail: gik49@yandex.ru
}

\begin{abstract}
*Supervising author; ${ }^{+}$Corresponding author
Keywords: alkali metals halogenides, specific electric conductivity, melts, analytical description, order number, ionic radius, ionic potential, electronegativity difference.
\end{abstract}

Abstract
In this paper, the analytical description of the specific conductivity of the potassium halogenides melts $\mathrm{KHal}(\mathrm{Hal}-\mathrm{F}, \mathrm{Cl}, \mathrm{Br}, \mathrm{I})$ is presented. The analitical description is provided on dependence of the specific conductivity on the halogen order number $\mathfrak{x}=\mathrm{f}(\mathrm{Z})$, the ionic radius of halogen-ion $æ=\mathrm{f}(\mathrm{r})$, the ionic potential $æ=\mathrm{f}(1 / \mathrm{r})$, the electronegativity difference $\mathfrak{x}=\mathrm{f}(\Delta \chi)((\Delta \chi=\chi(\mathrm{Hal})-\chi(\mathrm{K}))$. The interrelation of a reduced property with an order number $æ / Z=f(Z)$ is considered. According to the obtained analytical dependencies, the calculation of the value of the potassium astatide specific conductivity is given for temperatures above the melting point on $5,10,50,75,100,150$ и $200^{\circ}$, in literature Information for KAt absent. The calculation was carried out using comparative methods for calculating M.Kh. Karapetyan in the coordinates of "propertyparameter" and "property-property." Least squares method was applied for processing the analytical description results with the choice of optimal dependencies on the maximum correlation coefficient and the minimum standard deviation. The analysis of the interrelation of the calculated numerical values with similar characteristics for NaAt и LiAt is presented. Comparison of the specific conductivity obtained numerical values of the astatide potassium melt showed good consistency with the values $æ$ obtained from the straight line dependence $\mathfrak{x}_{\text {пл }+n}=a \cdot \mathfrak{x}_{\text {плл }+5}\left(\mathrm{n}=10^{\circ} \ldots .200^{\circ}\right)$ and also with similar characteristics for lithium astatide and sodium astatide. The analytical calculation results allow to describe the temperature dependence of the potassium halogenides specific conductivity, including KAt. The calculation method can be used to describe the melts specific conductivity in the same type series of compounds of alkaline and alkaline-earth elements that make up electrolytes for chemical current sources.

\section{References}

[1] M.Kh. Karapet'yants. Methods of comparative calculation of physical and chemical properties. Moscow: Chemistry. 1965. 403p. (russian)

[2] I.K. Garkushin, O.V. Lavrenteva, M.A. Istomova, A.N. Trunova, S.N. Parfenova, A.I. Garkushin, A.V. Kolyado. Methods for calculating the properties of elements, simple substances, compounds and mixes. Samara: SamGTU. 2017. 467p. ISBN 978-5-7964-2060-7 (russian)

[3] M.M. Viktorov. Methods for calculating physico-chemical quantities and applied calculations. Leningrad: Chemistry. 1977. 360p. (russian)

[4] V.M. Borishansky, S.S. Kutateladze, I.I. Novikov, O.S. Fedynsky. Liquid metal coolants. Moscow: Atomizddat. 1967. 299p. (russian)

[5] V.M. Agaga, I.L. Gnedaya. Alkali metals - production, properties, application. Questions of atomic science and technology. 2006. No.1. Series: Vacuum, pure materials, superconductors (15). P.184-194. (russian)

[6] G.I. Zamaldinova, S.N. Parfenova, A.I. Garkushin, I.K. Garkushin, V.V. Slepushkin. Properties of s ${ }^{1}-$ elements, simple substances, halogenides and their mixes: analytical description, calculation and interrelation: monograph. Samara: SamGTU. 2010. 202p. (russian)

[7] A.K. Charykov. Mathematical processing of the results of chemical analysis. Leningrad: Chemistry. 1984. 168p. (russian)

[8] A.N. Seidel. Errors of measurement of physical quantities. Moscow: Science. 1974. 108p. (russian)

[9] A.G. Morachevsky. Handbook of molten salts. Vol.1. Ed. A.G. Morachevsky. Leningrad: Chemistry. 1971. 168p. (russian) 
ANALYTICAL DESCRIPTION OF THE SPECIFIC ELECTRIC CONDUCTIVITY OF HALOGENIDES Khal... 138-145

[10] Emsli Dzh. Elements: translation from English. Moscow: Mir. 1993. 256p. (russian)

[11] V.A. Rabinovich, Z.Ya. Havin. Brief Chemical Handbook. Leningrad: Chemistry. 1977. 376p. (russian)

[12] M.V. Smirnov, Yu.A. Shumov, V.A. Khokhlov. The conductivity of molten alkali metal fluorides. Works of the Electrochemistry Institute of the Ural Scientific Center of the USSR Academy of Sciences. 1972. Iss.18. P.3-9. (russian)

[13] Shot handbook of physico-chemical variables. Under. ed. K.P. Mishchenko, A.A. Ravdel. Leningrad: Chemistry. 1974. 192p. (russian)

[14] A.I. Efimova, L.V. Belorukova, I.V. Vasilkova, V.P. Chechev. Properties of inorganic compounds. Handbook. Leningrad: Chemistry. 1983. 392p. (russian)

[15] I.I. Kornilov, N.M. Matveeva, L.I. Pryakhina, R.Kh. Polyakova. Metallochemical properties of the the periodic system elements. Moscow: Science. 1966. 352p. (russian)

[16] P.I. Bistrov, D.N. Kagan, G.A. Krechetova, E.E. Spielrain. Liquid metal heat carriers of heat pipes and power plants. Moscow: Science. 1988. 263p. (russian)

[17] The chemical encyclopedia in 5 volumes. Under ed. N.S. Zefirova. Vol.5. Moscow: Scientific publishing house «BRE». 1998. P.336. (russian)

[18] Physico-chemical properties of elements. Handbook ed. G.V. Samsonov. Kiev: Naukova Dumka. 1965. 808 p.

[19] K. Saito, S. Hayakova, F. Takei, X. Yamadera. Chemistry and the periodic table. Translation from Japanese. Moscow: World. 1982. 320p. (russian)

[20] G.J. Janz, R.P.T. Tomkins, C.B. Allen. Molten Salts: Vol. 4. Part 4. Mixed Halide Melts. J. Phys. Chem. Ref: Data 1979. Vol.8. No.1. P.125-283.

[21] G.J. Janz, R.P.T. Tomkins, C.B. Allen, Jr.J.R. Downey, G.L. Garner, U. Krebs, S.K. Singer. Molten salts: Vol.4. Part 2. Chlorides and mixtures, electrical conductance, density, viscosity, and surface tension data. J. Phys. Chem. Ref: Data 1975. P.871-1178.

[22] G.J. Janz, R.P.T. Tomkins. Molten Salts: Vol. 5. Part 2: Additional Multi-Component Salt Systems. J. Phys. Chem. Ref: Data 1983. No.12. P.591.

[23] M.P. Slavinsky. Physical and chemical properties of elements. Moscow: Metallurgizdat. 1952. 763p. (russian)

[24] I.K. Garkushin, G.I. Zamaldinova, A.I. Garkushin, I.M. Kondratuk. Analytical description of specific electric conductivity of alkali metal chlorides and its prediction for $\mathrm{FrCl}$ melt. J. Melts. 2008. No.5. P.84-88. (russian)

[25] I.K. Garkushin, E.G. Danilushkina, A.I. Garkushin, S.N. Parfenova. Analytical description of the specific conductivity of MJ melts $(\mathrm{M}-\mathrm{Li}, \mathrm{Na}, \mathrm{K}, \mathrm{Rb}, \mathrm{Cs})$ and its prediction for the FrJ melt. J. Melts. 2012. Vol.5. P.23-26. (russian)

[26] Table Curve 2D. Automated Curve Fitting \& Equation Discovery. Version 5.01. SYSTAT Software Inc, 2002.

[27] I.K. Garkushin, A.N. Trunova, A.I. Garkushin. Analytical description of the specific conductivity of lithium halogenides melts and its prediction for a LiAt melt. J. Melts. 2016. Vol.1. P.26-34. (russian)

[28] M.V. Runtov, S.N. Parfenova, G.I. Zamaldinova et al. Analytical description and prediction of the properties of metal and salt melts by polythermal and isothermal cross-sectional methods. Bulletin of the Samara Science Center of RAS "Chemistry and Chem. technology". Samara 2004. P.21-26.

[29] A.I. Garkushin, E.G. Danilushkina, I.K. Garkushin, S.N. Parfenova. Analytical description of the specific electric conductivity of MI melts $(\mathrm{M}-\mathrm{Li}, \mathrm{Na}, \mathrm{K}, \mathrm{Rb}, \mathrm{Cs})$ and its prediction for the FrI melt. $J$. Melts. 2012. Vol.5. P.23-26. (russian)

[30] I.K. Garkushin, O.V. Lavrentyeva, and Ya.A. Andreeva. Analytical description of critical properties of alkaline metals in the Li...Cs group and calculation of critical properties for francium. Butlerov Communications. 2017. Vol.52. No.12. P.129-133. DOI: 10.37952/ROI-jbc-01/17-52-12-129

[31] I.K. Garkushin, O.V. Lavrenteva, Ya.A. Andreeva, and V.M. Yakovlev. Analytical description of thermodynamic properties of alkaline metals and calculation them for francium. Butlerov Communications. 2018. Vol.54. No.4. P.34-39. DOI: 10.37952/ROI-jbc-01/18-54-4-34

[32] I.K. Garkushin, O.V. Lavrenteva, and Ya.A. Andreeva. Analytical description of the alkaline metals melts density and calculation of it for francium. Butlerov Communications. 2018. Vol.55. No.8. P.92101. DOI: $10.37952 /$ ROI-jbc-01/18-55-8-92

[33] A.B. Shubin, and A.V. Dolmatov. Mechanical and microstructure properties of the metallic composites based on gallium and containing InBi intermetallic compound. Butlerov Communications. 2017. Vol.50. No.6. P.61-65. DOI: 10.37952/ROI-jbc-01/17-50-6-61 
[34] A.B. Shubin, and L.F. Yamshchikov. Physico-chemical properties of metallic composite materials based on gallium. Butlerov Communications. 2017. Vol.50. No.4. P.141-145. DOI: 10.37952/ROI-jbc01/17-50-4-141

[35] I.K. Garkushin, A.I. Garkushin, E.G. Danilushkina, M.A. Istomova, Yu.V. Moschensky, and A.M. Shtelenberg. Analytical and graphical correlation between eutectic temperatures (minimum) and compositions of binary halide systems. Butlerov Communications. 2017. Vol.49. No.2. P.36-43. DOI: 10.37952/ROI-jbc-01/17-49-2-36

[36] I.K. Garkushin, G.I. Zamaldinova, A.I. Garkushin, S.N. Parfenova, E.G. Danilushkina, and E.I. Frolov. Analytical description of the LiCl-MCl (M-Na, K, Rb, Cs) low melting compositions and prediction of the LiCl-FrCl eutectic characteristics. Butlerov Communications. 2017. Vol.49. No.2. P.44-47. DOI: 10.37952/ROI-jbc-01/17-49-2-44 